\title{
Clinical management of childhood bruxism
}

\author{
Manejo clínico do Bruxismo na infância
}

\author{
Thays de Almeida ALFAYA ${ }^{1}$ \\ Patrícia Nivoloni TANNURE² \\ Roberta BARCELOS 3 \\ Etyene Castro DIP3 \\ Luciana UEMOTO' \\ Cresus Vinícius Depes GOUVÊA 4
}

\begin{abstract}
This paper aims to report the case of a 9-year-old male patient presented to the Pain Clinic at the education institution with a severe complaint of headache and clenching. During clinical examination, facets of tooth wear and accentuated overjet were observed. There were no joint and I or muscle anomalies. Therapy adopted was an occlusal splint with occlusal adjustments in centric performed every fifteen days in order not to impair bone growth and eruption of permanent teeth. After one month of treatment, the patient showed pain remission and remained in monitoring of dental and psychological care.
\end{abstract}

Indexing terms: Bruxism. Child. Therapeutics.

\section{RESUMO}

Este trabalho objetiva relatar o caso clínico de um paciente do sexo masculino, nove anos de idade, que compareceu a Clínica da Dor de uma instituição de ensino superior com queixa principal de cefaléia e apertamento dentário em vigília. Ao exame clínico, observou-se facetas de desgaste dentário e transpasse horizontal acentuado. Não foram observadas alterações articulares e/ou musculares. A terapêutica adotada foi à confecção de placa miorrelaxante em resina acrílica termoplastificável com ajustes oclusais em cêntrica realizados a cada quinze dias de forma não prejudicar o crescimento ósseo e a erupção dos dentes permanentes. Após um mês de tratamento o paciente apresentou remissão da dor e foi orientado a reduzir o tempo de uso da placa miorrelaxante. O paciente mantém-se em acompanhamento odontológico e psicológico.

Termos de indexação: Bruxismo. Criança. Terapêutica.

\section{Introduction}

Bruxism is considered an involuntary nonfunctional activity of the masticatory system ${ }^{1-2}$ and is characterized by teeth clenching or grinding ${ }^{3-4}$. Classified as a psychophysiological disorder, it may occur during sleep or waking, consciously or unconsciously ${ }^{3}$. This habit is common during childhood ${ }^{5-6}$ and may have negative consequences on the stomatognathic system ${ }^{7}$. Its prevalence in children ranges from $7 \%$ to $15.1 \%^{8}$ and girls are more often affected ${ }^{9}$.

The etiology of bruxism is not completely elucidated ${ }^{10}$ and may involve local, systemic and psychological factors, or be related to sleep disorders ${ }^{7}$. The diagnosis of sleep consists of clinical signs and symptoms such as tooth wear, pain in the facial muscles, headaches reported or observed by polysomnographic changes (in cases of nocturnal bruxism).
Injuries in the tooth structure and supporting tissues of the resulting bruxism can lead to hypersensitivity to temperature changes, tooth mobility, injuries in the periodontal and periodontal ligament, hypercementosis, fracture cusps, pulpitis and pulp necrosis ${ }^{11}$. Other complications associated with bruxism include gum recession, bone resorption, hypertrophy of mastication muscles and temporomandibular disorders ${ }^{12}$.

Clinical interventions aim to protect dental structures, reduce ranger, relief facial and temporal pain and promote improvements in sleep quality ${ }^{2,13}$. The beginning of treatment is indicated when frequency, intensity and duration of the disorder begin to interfere with the normal development of the stomatognathic system orofacial structures ${ }^{3}$. However, there are controversies in literature regarding diagnosis and therapy and further studies are needed to fill this gap. Thus, the aim of this study was to present a case report of a child

\footnotetext{
${ }^{1}$ Universidade Salgado de Oliveira, Curso de Odontologia. Niterói, RJ, Brasil.

${ }^{2}$ Universidade Veiga de Almeida, Rio de Janeiro, RJ, Brasil.

${ }^{3}$ Universidade Federal Fluminense, Faculdade de Odontologia, campus Nova Friburgo. Rua Dr. Silvio Henrique Braune, 22, 28625-650, Nova Friburgo, RJ, Brasil. Correspondência para / Correspondence to: RBARCELOS. E-mail: <rbarcelos@id.uff.br>

${ }^{4}$ Universidade Federal Fluminense, Faculdade de Odontologia, campus Valonguinho, Niterói, RJ, Brasil
} 
with temporal headache history, clenching and facets wear and discuss the diagnosis of bruxism and the success of the clinical management of this pathology.

\section{Case report}

Nine-year-old black male patient presented to the "Clínica da Dor" of the school of dentistry of a private university of Rio de Janeiro accompanied by his parent with severe complaint of headache in the temporal region that persisted for two months. The patient reported that the pain showed up sporadically, pulsatile and momentary, starting with head movement. Furthermore, the child had a habit of biting the cheek and performing clenching awake, while watching TV and playing video games, not realizing the habit during sleep.

On clinical examination, healthy mixed dentition with the presence of facets wear in permanent anterior teeth and primary posterior teeth was observed. The patient was classified as Angle class II with severe overjet (Figures 1, 2 and 3) but without occlusal interferences. Signs of anxiety such as agitation, hyperactivity and hurry to finish dental appointment were observed during appointment. During extraoral clinical examination no joint or muscle changes were observed. The diagnosis of bruxism was based on patient and mother's report and on dental changes observed.

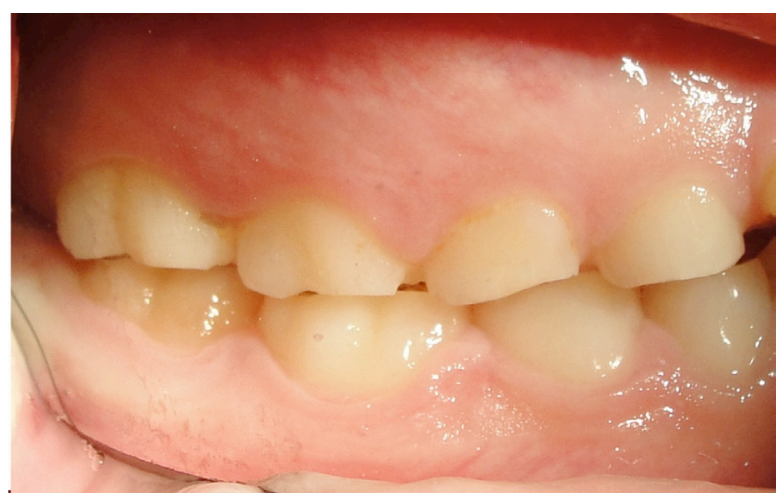

Figure 1. Lateral view (right) showing the wear facets.

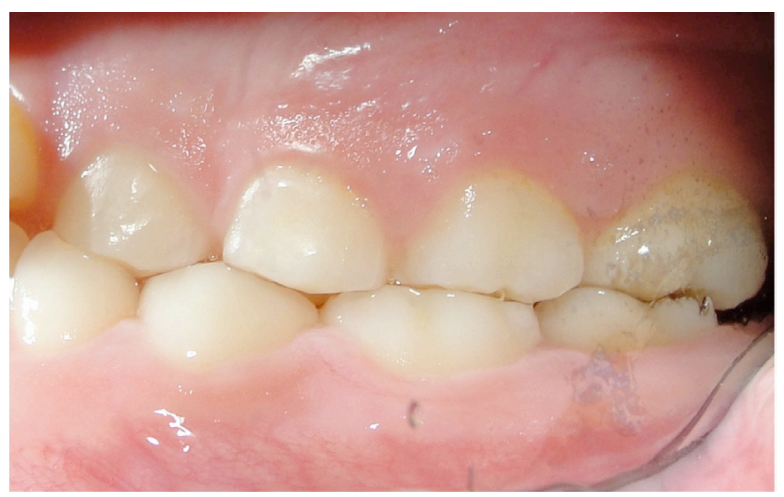

Figure 2. Lateral view (left) showing the wear facets.

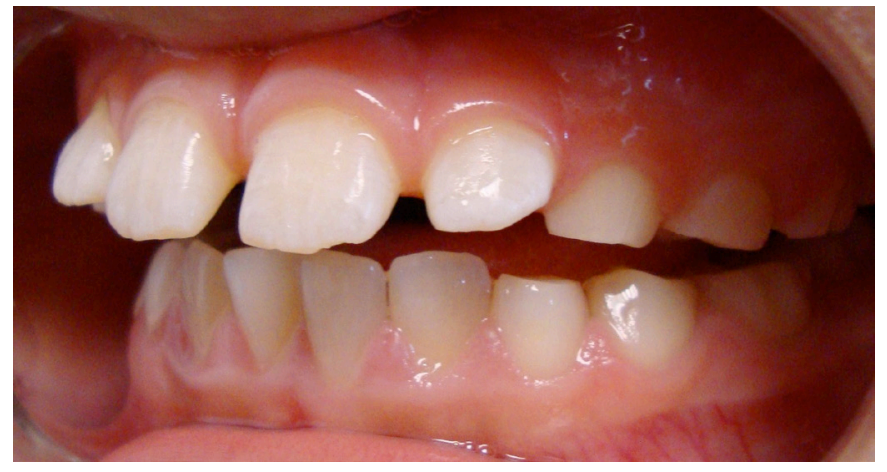

Figure 3. Anterior view showing the severe overjet.

In the presence of wear facets (Figures 1, 2, 4 and 5) and painful symptoms, occlusal splint in thermoplastic acrylic resin adapted to the lower arch was adopted as therapeutic approach (Figure 6). The choice of the lower plate was related to the sharp overjet and for aesthetic reasons. The patient was instructed to use in the period of the parafunctional habit and was encouraged to seek psychological assistance. Dental visits were scheduled every fortnight for occlusal adjustments on the board in order not to hinder bone growth and eruption of permanent teeth.

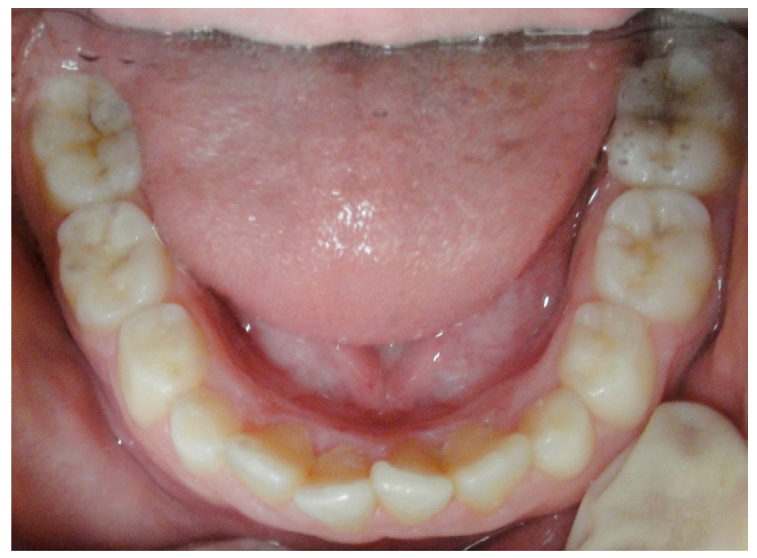

Figure 4. Oclusal view (lower).

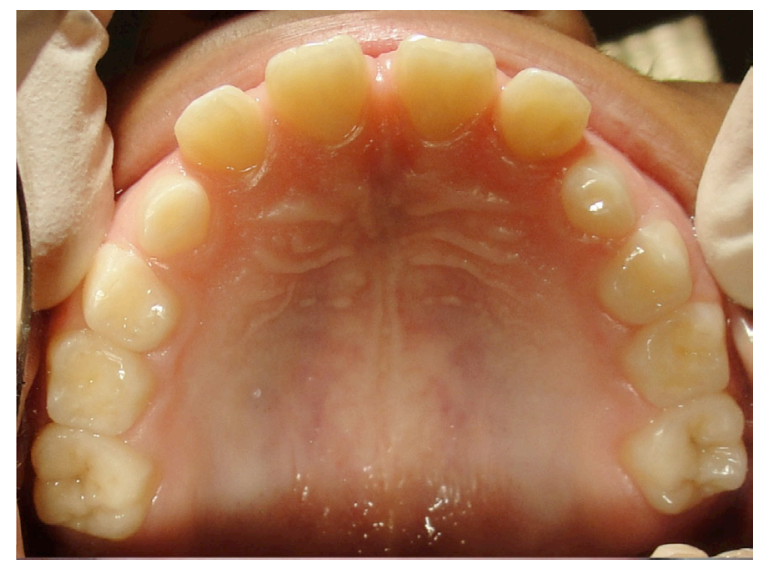

Figure 5. Oclusal view (upper). 


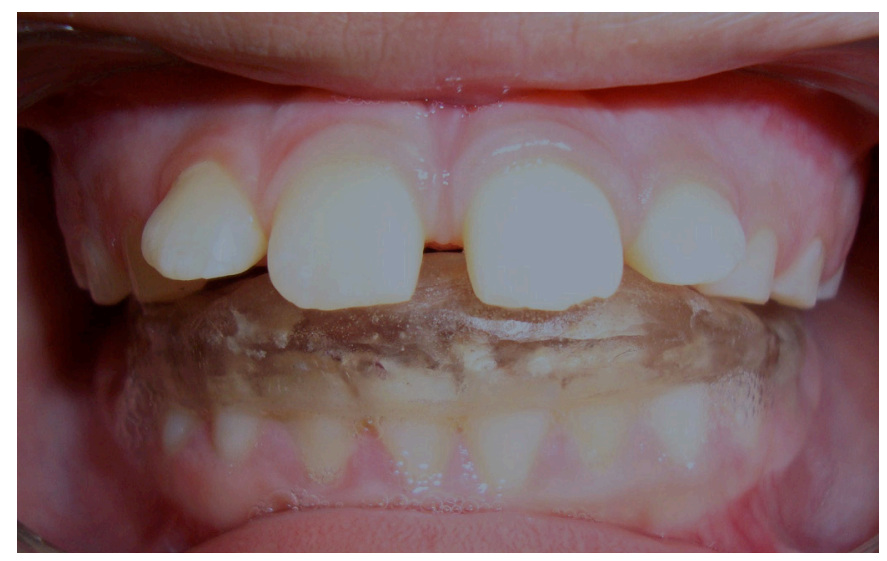

Figure 6. Occlusal splint in position.

After one month of treatment, the patient had remission of symptoms; however, awake clenching still remained. Treatment with plate was maintained to avoid further damage to the tooth structure and support tissues. The patient was advised and sent to carry out Orthodontic treatment.

Patient care observed the respect for ethical principles contained in the Declaration of Helsinki and meeting specific Brazilian legislation. Parents and/or guardians signed the informed consent form.

\section{DISCUSSION}

The association between bruxism intensity and frequency and damage to dental structures is not yet fully understood in scientific literature ${ }^{5}$ but it is essential to establish the timing of clinical interventions. The aim of bruxism treatment is to improve the patient's sleep quality (in the case of nocturnal bruxism), remission of painful symptoms, decrease in wear facets in canines and molars and to avoid disorders in the temporomandibular joint and periodontal structure. Although the relationship between the occurrence of bruxism and TMD is not well understood in literature ${ }^{5}$, some studies have show that prevention of deleterious habits in childhood can lead to a decrease in TMD disorders ${ }^{14-15}$.

In this case report, clenching was associated with headache and high levels of anxiety. Although these features can be common in children at school age, they are usually related to the early onset of bruxism and when taken together, it characterizes this condition 1,14-21.

The treatment of bruxism is a controversial subject. Among the treatment options include the use of psychological techniques ${ }^{22}$, adenotonsillectomy in cases of bruxism associated with difficulties resporatórias ${ }^{23}$ and occlusal splint ${ }^{24}$, without strong scientific evidence about the prevalence of a therapy ${ }^{21}$. Occlusal splint plays a fundamental orthopedic role in order to quickly erase the occlusal memory by balancing occlusion and reducing wear facets ${ }^{7}$. It is known that the occlusion is an etiological factor of bruxism ${ }^{20}$, although its removal does not completely eliminate the habit. In our case, there has been no occlusal interference, and the use of appliance is aimed to promote changes in muscle activity and to stop the habit, preventing damage to periodontal structures and minimizing the adverse effects of prolonged overcharging 19-22,25-27.

The choice of occlusal splint was mainly related to aesthetic issues and the advantage of better chance of talking on its use ${ }^{4}$. Although the patient had a severe overjet, the occlusal splint was manufactured reproducing an ideal occlusion pattern, or mutually protected occlusion, wherein the further contacts are stronger than the earlier, not allowing increased mesmo ${ }^{4}$. Their use does not exceed the period of six months, thereby not compromise the physiological correction of overjet as the upper lip touch the dental elements.

Although literature indicates the occlusal splint as an alternative treatment in childhood bruxism ${ }^{7,17,28}$, there is no consensus about which parameters to consider for its replacement. There is a recommendation for continuous monitoring ${ }^{29}$ without setting ranges. In the absence of well-established criteria, clinical and radiographic and patient age data are used as a reference for observation of bone growth, exfoliation and eruption of teeth and determination of the time to introduce a new appliance. Due to that fact that the patient is a child, internal and external adjustments were made in a range greater than recommended for adults, ie every two weeks. For treatment discontinuation, the observation of the evolution of symptoms was followed as protocol. So from the moment the patient reported improvement of symptoms, the use of the appliance was lowered until the use is limited to the time of the habit. Then, the use is advocated in alternate days and if there were no deterioration complaints, there would be an even greater reduction time. As improvement of symptoms occurred, the use must be reduced again until the patient stay a few days without the plate. At that time or during treatment the plate could no longer fit due to bone growth, so new board would be made if there were return / persistent symptoms, and / or severe tooth wear.

The importance of interdisciplinary treatment in patients with orofacial pain should be emphasized. The beginning of treatment is aimed at eliminating the main 
complain, the daily headache. The patient then was referred for psychological evaluation due to anxiety and agitated behavior during consultations. Psychologist reported that the patient presents speech developmental disorder, poor academic performance and anxiety disorder associated with night terrors.

The second moment of the therapeutic approach, but not least, should include the resolution of aesthetic and functional changes. The orthodontic analysis is a point worth mentioning, since malocclusion can be one of the etiologic factors of orofacial pain. Moreover, isolated, malocclusion has not been identified as a determinant of temporomandibular dysfunctions ${ }^{30}$. Patients' severe overjet indicated the need for orthodontic intervention and monitoring the development of temporomandibular joint. However, orthodontic treatment was not the option of choice, as the responsible reported no financial conditions for its performance at that time. Thus, the conduct in "Clínica da Dor" was related to the relief of patients' pain symptoms.

Therefore, it is consensus that bruxism treatment in childhood would initially eliminate pain related to parafunctional habit and later planning with or without orthodontic intervention aimed at developing the

\section{REFERÊNCIAS}

1. Bloomfield ER, Shatkin JP. Parasomnias and movement disorders in children and adolescents. Child Adolesc Psychiatr Clin N Am. 2009;18(4):947-65.

2. Widmalm SE, Gunn SM, Christiansen RL, Hawley LM. Association between CMD signs and symptoms, oral parafunctions, race and sex, in 4-6-year-old African-American and Caucasian children. J Oral Rehabil. 1995;22(2):95-100.

3. Gusson DGD. Bruxismo em crianças. J Bras Odontopediatr Odontol Bebe. 1998;1(2):75-97

4. Okeson JP. Tratamento das desordens temporomandibulares e oclusão. São Paulo: Elsevier; 2008.

5. Barbosa TS, Miyakoda LS, Pocztaruk Rde L, Rocha CP, Gaviao MB. Temporomandibular disorders and bruxism in childhood and adolescence: review of the literature. Int J Pediatr Otorhinolaryngol. 2008;72(3):299-314

6. Santos ECA, Bertoz FA, Pignatta LMB, Arantes FM. Avaliação clínica de sinais e sintomas da disfunção temporomandibular em crianças. Rev Dental Press Ortodon Ortop Facial. 2006;11(2):29-34.

7. Pizzol KEDC, Carvalho JCQ, Konishi F, Marcomini EMS, Giusti JSM. Bruxismo na infância: fatores etiológicos e possíveis tratamentos. Rev Odontol UNESP. 2006;35(2):157-63.

8. Lobbezoo F, van Der Zaag J, Naeije M. Bruxism: its multiple causes and its effects on dental implants - an updated review. J Oral Rehabil. 2006;33(4):293-300. physiology of bone and tooth structures. In the present case, occlusal splint was an effective therapy and interruption of headache showed the onset of a successful treatment.

\section{Conclusions}

The presence of wear facets in permanent teeth associated with constant headaches indicates that the dentist is facing a case of bruxism. In this case report, occlusal splint was presented as an excellent therapy for the resolution of headache, the main patient's complaint. However, there is still the need for further long-term clinical studies, showing the time and the best form of treao be used in cases of childhood bruxism.

\section{Collaborators}

TA ALFAYA was responsible for the clinical care of the patient as well as the writing of the article. BARCELOS R and $L$ Uemoto guided the clinical care of patient and PN Tannure performed the text revision, EC DIP and CVD GOUVÊA performed the preparation and revision of the text.

9. Serra-Negra JM, Paiva SM, Seabra AP, Dorella C, Lemos BF, Pordeus IA. Prevalence of sleep bruxism in a group of Brazilian schoolchildren. Eur Arch Paediatr Dent. 2010;11(4):192-5.

10. Bayardo RE, Mejia JJ, Orozco S, Montoya K. Etiology of oral habits. ASDC J Dent Child. 1996;63(5):350-3.

11. Cariola TC. O desenho da figura humana com bruxismo. Bol Psicol. 2006;61(124):37-52.

12. Castelo PM, Barbosa TS, Gaviao MB. Quality of life evaluation of children with sleep bruxism. BMC Oral Health. 2010;10:16.

13. Weideman CL, Bush DL, Yan-Go FL, Clark GT, Gornbein JA. The incidence of parasomnias in child bruxers versus nonbruxers. Pediatr Dent. 1996;18(7):456-60.

14. Farsi N, Alamoudi N, Feteih R, El-Kateb M. Association between temporo mandibular disorders and oral parafunctions in Saudi children. Odontostomatol Trop. 2004;27(106):9-14.

15. Kritsineli M, Shim YS. Malocclusion, body posture, and temporomandibular disorder in children with primary and mixed dentition. J Clin Pediatr Dent. 1992;16(2):86-93.

16. Bader G, Lavigne G. Sleep bruxism; an overview of an oromandibular sleep movement disorder. REVIEW ARTICLE. Sleep Med Rev. 2000;4(1):27-43.

17. Diniz MB, Silva RC, Zuanon ACC. Bruxismo na infância: um sinal de alerta para odontopediatras e pediatras Rev Paul Pediatr. 2009;27(3):329-34.

18. Brna PM, Dooley JM. Headaches in the pediatric population. Semin Pediatr Neurol. 2006;13(4):222-30. 
19. Carotenuto M, Guidetti V, Ruju F, Galli F, Tagliente FR, Pascotto A. Headache disorders as risk factors for sleep disturbances in school aged children. J Headache Pain. 2005;6(4):268-70.

20. Guidetti V, Federica G. Headache in children: diagnostic and therapeutic issues. Sem Pain Med. 2004;2(2):106-14.

21. Restrepo C, Gomez S, Manrique R. Treatment of bruxism in children: a systematic review. Quintessence Int. 2009;40(10):84955.

22. Restrepo CC, Alvarez E, Jaramillo C, Velez C, Valencia I. Effects of psychological techniques on bruxism in children with primary teeth. J Oral Rehabil. 2001;28(4):354-60.

23. Difrancesco RC, Junqueira PA, Trezza PM, De Faria ME, Frizzarini $\mathrm{R}$, Zerati FE. Improvement of bruxism after T \& A surgery. Int J Pediatr Otorhinolaryngol. 2004;68(4):441-5.

24. Hachmann A, Martins EA, Araujo FB, Nunes R. Efficacy of the nocturnal bite plate in the control of bruxism for 3 to 5 year old children. J Clin Pediatr Dent. 1999;24(1):9-15.

25. Alencar-Junior FGP. Disfunções temporomandibulares musculares. In: Alencar-Junior FGP, Fricton JR, Hathaway K,
Decker K. Oclusão, dores orofaciais e cefaléia. São Paulo: Santos; 2005. p. 93-5.

26. D'cruz OF, Vaughn BV. Parasomnias--an update. Semin Pediatr Neurol. 2001;8(4):251-7.

27. Sheldon SH. Parasomnias in childhood. Pediatr Clin North Am 2004; 51(1): 69-88, vi.

28. Campos JaBD, Campos AG, Zuanon ACC. Bruxismo em crianças. RGO - Revv Gaúch Odontol. 2002;50(2):74-6.

29. Antonio AG, Pierro VS, Maia LC. Bruxism in children: a warning sign for psychological problems. J Can Dent Assoc. 2006;72(2):155-60.

30. Bósio JA. O paradigma da relação entre oclusão, ortodontia e disfunção têmporo-mandibular. Rev Dent Press Ortodon Ortop Facial. 2004;9(6):84-9.

Received on: 14/6/2010

Final version resubmitted on: 9/10/2010

Approved on: 17/11/2010 
TA ALFAYA et al. 